\title{
THE ROLE OF PEPSIN, PEPTIC INHIBITORY SUBSTANCES, AND HYDROCHLORIC ACID IN NORMAL SUBJECTS AND IN THE PRODUCTION OF PEPTIC ULCERS ${ }^{1}$
}

\author{
By HARRY H. LE VEEN AND LEONARD HALLINGER
}

(From the Department of Surgery of the University of Chicago)

(Received for publication July 23, 1946)

\section{INTRODUCTION}

There is still disagreement as to the respective roles of the pepsin and hydrochloric acid of gastric juice in the production of duodenal ulcer.

In patients with ulcer, free hydrochloric acid has been generally found to be present in increased quantities $(1,2)$. The work of Dragstedt (3) and of Mann and Bollman (4) have tended to emphasize the importance of hydrochloric acid.

The occurrence of ulcers following the surgical shunting of alkaline secretions (bile and pancreatic juice) away from those portions of intestines where gastric juice was made to enter, served in part as a basis for their deductions. Dragstedt, in addition, pointed out that the rate of digestion of frog's leg in an acid pepsin solution was dependent on acid concentration and independent of pepsin concentration (5). The production of ulcers by feeding hydrochloric acid to experimental animals also served as a basis for their conclusions. Histamine is a potent secretagogue of hydrochloric acid (6), but not of pepsin (7). Ulcers have been produced in practically all species of animals by injection of histamine in beeswax (8). Cases have even been reported in humans following injections of histamine (9). Frequent success over a long period with therapy employing antacids has been another strong argument in support of this premise.

Vanzant, Osterberg, Alvarez, and Rivers (10) have shown that the secretion of pepsin is enhanced in ulcer patients as compared with normal individuals and that a direct correlation existed between the amount of pepsin in gastric juice and the severity of symptoms. Mullins and Flood (11) and others (12) have confirmed these observations. Schiffrin (13) demonstrated that ulcers could be produced by perfusing isolated loops of jejunum or ileum of cats with pepsin and hydro-

\footnotetext{
1 Done on a grant from the Otho S. A. Sprague Memorial Institute.
}

chloric acid solution. Such ulcers were not produced by perfusion with hydrochloric acid alone. Driver's (14) investigations with dogs have yielded comparable results. Matzner (15) was able to produce ulcers in rats by feeding pepsinhydrochloric acid mixtures.

In any attempt to resolve the controversy over the comparative importance of acid and pepsin, it is necessary to apply more refined quantitative methods of study and to devise mutually exclusive experimental conditions wherein both factors do not vary in the same direction simultaneously.

Accurate determinations of gastric hydrochloric acid are easily made, but most methods for determining pepsin have been either inadequate or cumbersome (16). The reason for inadequacy lies partially in the method and partially in the failure to take cognizance of the kinetics of the enzyme (pepsin) reaction.

\section{THE KINETICS OF THE ENZYME REACTION}

Pepsin acts on proteins, splitting them into proteoses, peptones, and polypeptides, but not to the amino acid state (17). In the case of egg albumen, the molecule is either attacked and broken down to a molecular weight of approximately 1,000 , or it is not attacked at all (18). Pepsin has a predilection for certain peptide linkages, especially those involving tyrosine and phenylalanine (19). Unlike linkages are split at various rates (19). Pepsin does not act like some simple inorganic catalysts whose mere presence in traces is sufficient to bring about change. This enzyme reaction has been found to obey the Law of Mass Action, so that the rate of reaction and therefore the amount of substance converted are directly proportional both to the amount of active enzyme and to the concentration of active substrate present. However, the rate of conversion is not uniform for more than a brief period. The reaction rate rap- 


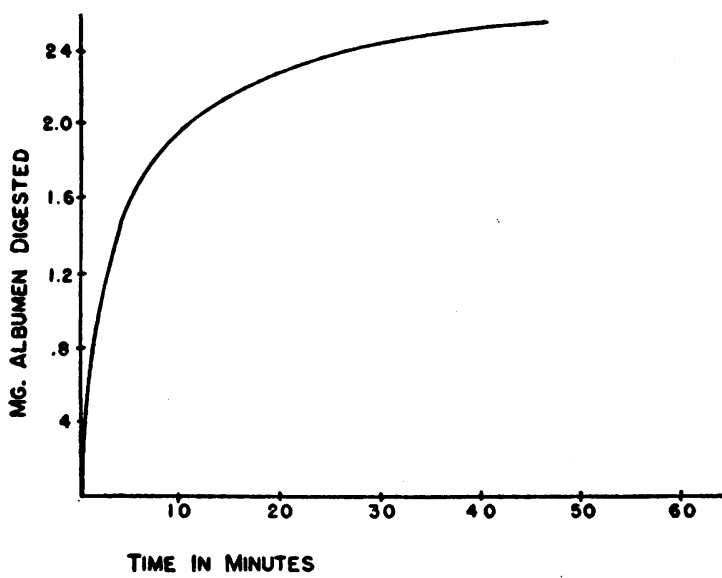

Fig. 1. The Amount of Protein Digested is Plotted against Time in Minutes. The Rate of Digestion Steadily Decreases, Reaching a Plateau in 30 Minutes

idly diminishes and approaches zero (Figure 1). Peptones, ${ }^{2}$ the product of pepsin digestion, combine with the active enzyme to form an inactive pepsin complex. Therefore the quantity of active enzyme present is constantly diminishing as digestion progresses. After the reaction rate has leveled off, the addition of sizeable increment of enzyme fails to produce further digestion, since the small quantity of pepsin initially present has produced large amounts of peptone inhibitor. It is the concentration of these inhibitory substances which determines the amount of pepsin which is active.

This pepsin-peptone complex has also been found by Northrop (20) to obey the Law of Mass Action, so that the following equation applies:

\section{Pepsin + Peptone $\leftrightarrows$ Pepsin-Peptone and \\ $\frac{\text { Conc. pepsin } \times \text { Conc. peptone }}{\text { Conc. pepsin-peptone }}=K$.}

The equation illustrates the reversibility of the reaction. Thus, if one decreases the concentration of the peptone inhibitors by dilution, active enzyme

2 Northrop uses the word "peptones" loosely to include all those breakdown products of protein which combine with pepsin. We have retained his definition. We have also included gastric inhibitory substances with peptones, since they certainly react like them and for the purposes of this paper may be considered identical. is liberated from the pepsin-peptone complex and additional digestion occurs. The significance of these concepts will be enlarged upon later in this paper.

The rate of digestion, as heretofore mentioned, is directly proportional to the rate of concentration of the active substrate (21) which is steadily diminishing during digestion. This, together with the fact that the enzyme is being progressively inactivated during digestion, does not allow for the expression of a direct linear relationship between the enzyme concentration and the amount of protein digested under practical test conditions. Northrop (20) has found the kinetics of the reaction to conform to the following equation:

$$
\frac{A \log \frac{A}{A-x}-x}{E T}=K
$$

$A=$ Substrate concentration

$x=$ Quantity of substrate converted

$E=$ Total enzyme concentration (active and $T=$ Time inactive)

Under the experimental conditions of our test, the amount of protein digested is directly proportional to the logarithm of the total pepsin concentration (Figure 2).

Protein is an amphoteric substance and is present in the form of kations in a solution acid to its isoelectric point (22). Pepsin acts only on pepsin kations. (The effect of hydrogen ion concentration on pepsin digestion is purely on the substrate and not on the enzyme [23].)

The percentage of protein present in its kationic form increases as the $\mathrm{pH}$ of the solvent decreases until 100 per cent is in the kationic form. Thereafter, further decrement in $\mathrm{pH}$ will reduce the number of protein kations by the common ion effect. An increase in the active kationic substrate, brought about by $\mathrm{pH}$ changes, augments the rate of digestion according to the Law of Mass Action. Since the $\mathrm{pH}$ at which all protein is in its kationic form varies from protein to protein, the optimum digestion $\mathrm{pH}$ of proteins differs. Peptic digestion of mucosa mimics egg albumen in that both have their optimum digestion $\mathrm{pH}$ in the region of 1 (24). The digestion of mucosa may therefore be compared to egg albumen. 


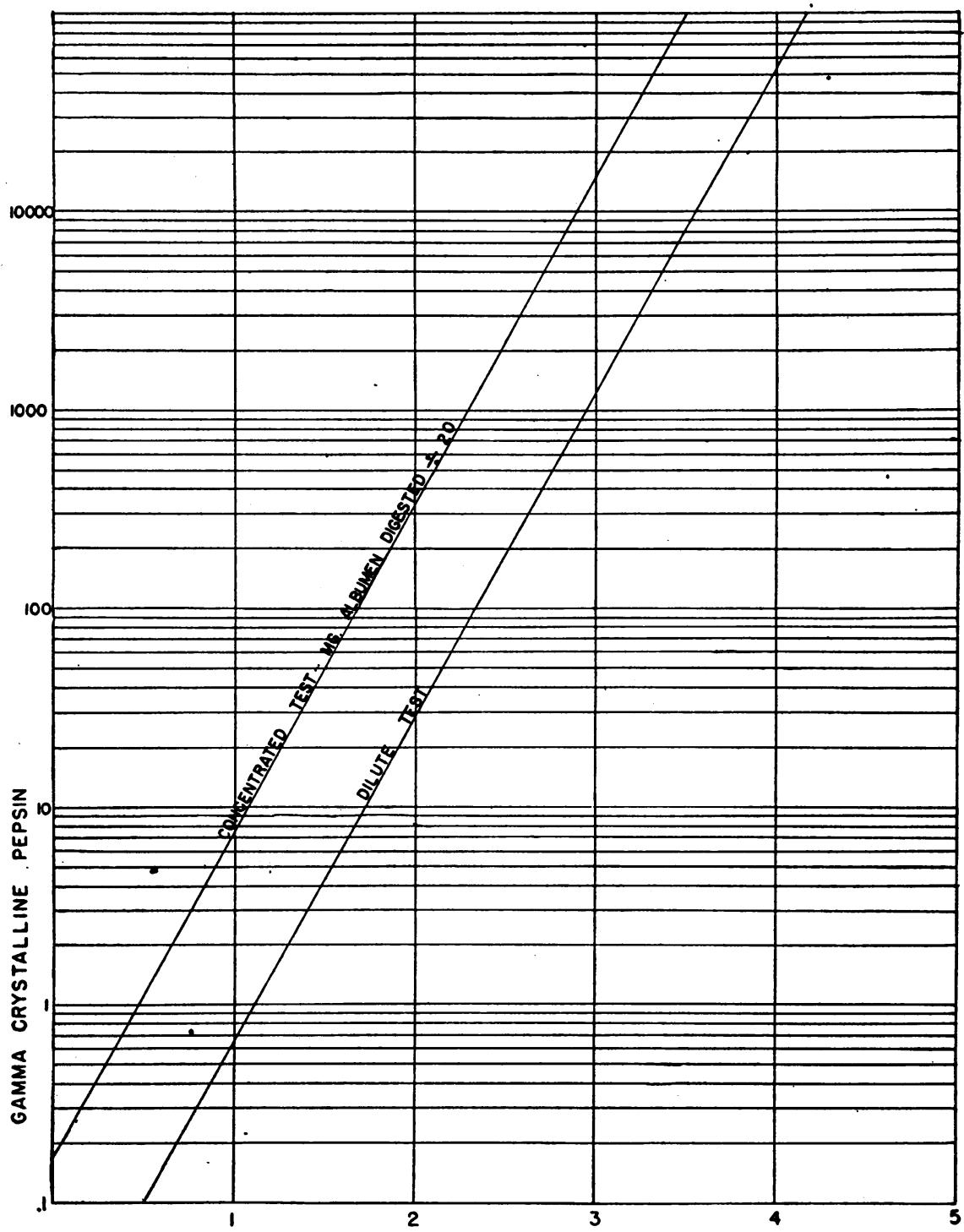

MG. ALBUMEN DIGESTED

Fig. 2. The Number of Milligrams Albumen Digested is Plotted against Gamma of Crystalline Pepsin on Semilogarithmic Paper for Both the Dilute AND The Concentrated Tests

In the concentrated test, $21 / 2 \times$ the enzyme concentration produces $20 \times$ the amount of albumen digested.

\section{APPLICATION OF ENZYME KINETICS TO THE STUDY OF GASTRIC JUICE}

In gastric juice, the estimation of pepsin activity is complicated by the presence of inhibitory substances analogous to peptones (25). These substances, formerly called anti-enzymes (26), have been thought to play an active role in protecting against autodigestion $(26,27)$. Langenskiöld
(28) indicated that these substances were probably peptones. It may be that the inhibitors of the gastric juice are peptones formed by the action of pepsin on proteins derived from food, mucosal cells, and secreted protein (mucin and plasma protein).

Dilution of gastric juice, under any conditions, by decreasing the concentration of inhibitory sub- 
stances (peptones), allows digestion to continue unimpeded. By using highly diluted juice one can assay the total quantity of pepsin present unaffected by the naturally occurring inhibitory substances. Conversely, when one uses low dilutions, one assays only that fraction of pepsin which is uncombined with the naturally occurring inhibitory substances, which we have called the Active Fraction. Bucher, Grossman and Ivy (29) have found that separation is usually complete at $1: 100$ dilution so that no further augmentation in pepsin activity occurs on continued dilution.

The preceding discussion poses the corollary if tests were performed on undiluted gastric juice, only that fraction of pepsin uncombined with inhibitor would be measured. Even when the gastric juice is mixed with concentrated substrate, however, dilution is unavoidable. In order to correct for this dilution, a curve correlating low dilution of gastric juice with quantity of substrate de- composed has been constructed (Figure 3). (This relationship is observed only in low dilutions.) This establishes that one can interpolate to the undiluted state in order to determine the amount of pepsin in gastric juice that remains unaffected by the inhibitory substances present (30).

We have assayed Total Pepsin Activity at optimum $\mathrm{pH}$ utilizing high dilutions of gastric juice (16). At the same $\mathrm{pH}$ we have assayed that amount which remains uninhibited (active fraction) by employing low dilutions of gastric juice and interpolating to the undiluted state. The per cent of pepsin inhibition may be thus derived.

Alterations in pepsin activity of this active fraction, produced by variation of $\mathrm{pH}$ from the optimum, are depicted graphically (Figure 4). It is evident that the acidity of different gastric juices varies significantly from this optimum. Hence the activity of the pepsin will vary and can be computed by reference to the figure. This pep-

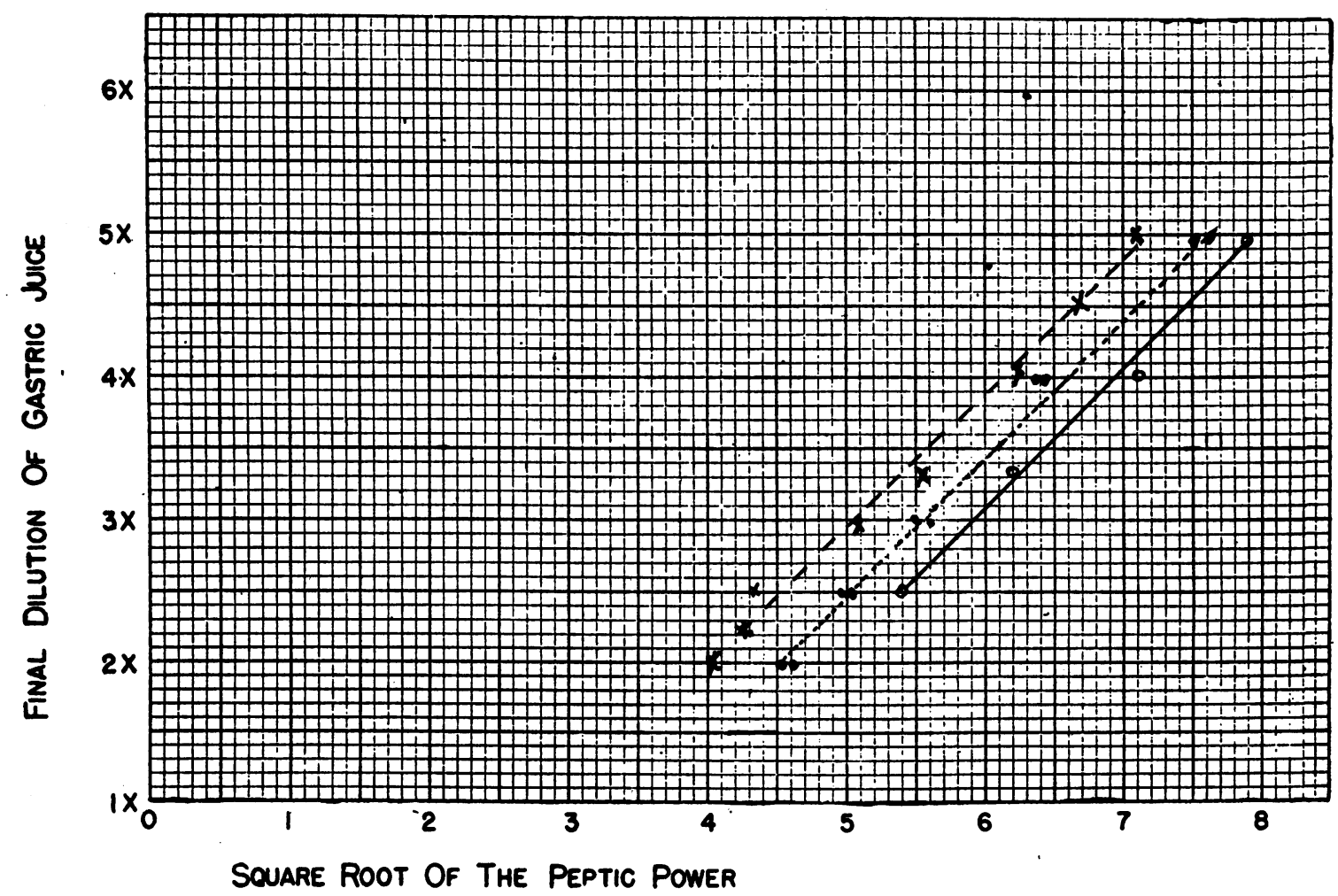

Fig. 3. Shows the Relationship of Dilution (3 Different Gastric Juices) to the Square Root of the Milligrams of Albumen Digested per ml. of Gastric Juice

$1 \mathrm{x}$ is point of no dilution. The represented relationship is $1: 1$ so that each increase of $1 \mathrm{x}$ in dilution increases the square of the peptic power 1 . 


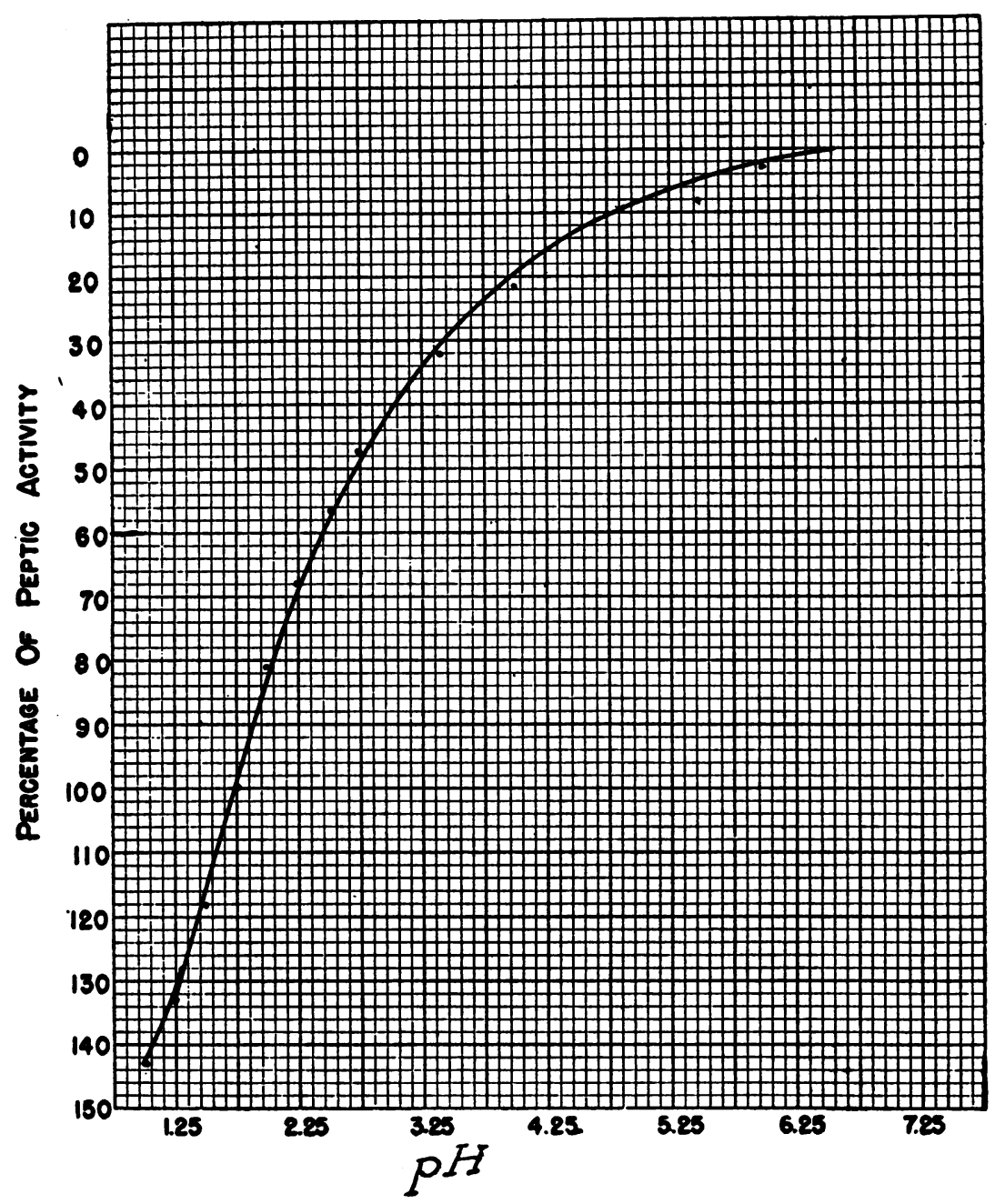

Fig. 4. Digested Protein, Represented as the Percentage of Protein Digested at pH 1.75 (100 per cent), is Plotted against the Hydrogen Ion Concentration of the Digestion Mixture Expressed in pH Units

sin activity, corrected for the effect of inhibitor substances and of $\mathrm{pH}$, we have designated Resting Peptic Activity. It is a measure of the pepsin activity which the gastric and duodenal mucosa are ' resisting in the basal secretory state.

To reiterate, total pepsin activity is merely an index of the secretory activity of the pepsinogenic cells of the gastric mucosa, but does not indicate the true digestive activity of the gastric juice as. modified by the inhibitor substances and hydrogen ion concentration.

Since inhibitory substances and $\mathrm{pH}$ play such a significant role in the kinetics of the pepsin reaction, it would seem important to know how much pepsin is inhibited via each mechanism in normal and ulcer patients. $U p$ to the present, there has been no information in the literature concerning this.

\section{MATERIALS AND METHODS}

All determinations were performed 4 to 8 hours after collection of the gastric juice: $\mathrm{pH}$ was determined with a glass electrode.

The methods for pepsin measurements have been described in detail elsewhere $(16,30)$. A brief outline is given to provide the reader with some conception both of the technic and the derivation of the units.

By precipitating various concentrations of albumen with sulfosalicylic acid under conditions of dilution and hydrogen ion concentration similar to those carried out in 


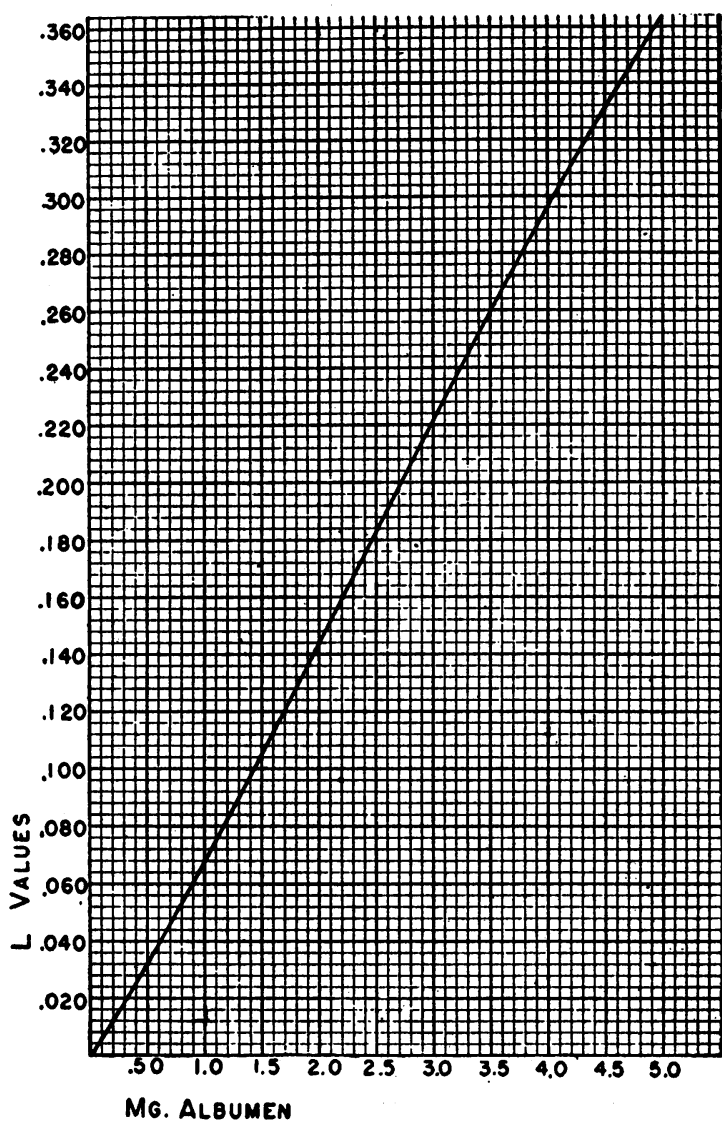

Fig. 5. Shows the Relationship of mgm. Albumen Precipitated by Sulfosalycylic Acid to Optical DenSITY EXPRESSEd AS L-Values

the test, and recording the turbidity in the Evelyn Colorimeter, a nomogram was constructed which related optical density, or $\mathrm{L}$ values (Figure 5 ) to mgm. of albumen present and enabled one to determine by difference the amount of albumen digested.

Although the pepsin determinations in both tests have been standardized against crystalline pepsin,,$^{3}$ it has been deemed desirable to use relative units, Pepsin Equivalents, instead, because there is no uniformity of activity among the various crystalline preparations of pepsin (31). Our pepsin equivalent unit is equal to 0.076 gamma of crystalline pepsin. (About 50 per cent of this preparation is magnesium sulfate.)

\section{Dilute test-assay of total pepsin}

Five mgm. of egg albumen is incubated for 30 minutes at $37^{\circ} \mathrm{C}$. with diluted gastric juice so that the final dilution is $1 / 563$. The mgm. albumen digested are determined by precipitating with sulfosalicylic acid after inactivating

3 The crystalline pepsin used in this study was obtained from the Plaut Research Laboratories, Bloomfield, N. J. the pepsin with sodium hydroxide. Units proportional to actual quantities of crystalline pepsin are obtained by expressing the results as the antilogarithm of the mgm. albumen digested. By multiplying the dilution factor, the final result, total pepsin, is designated in pepsin equivalents per ml. of gastric juice.

\section{Concentrated test-assay of active pepsin}

Undiluted gastric juice is mixed with concentrated albumen solution and hydrochloric acid solution so that the final dilution of the gastric juice is in the order of $1 / 4$. Digestion is carried out at $37^{\circ} \mathrm{C}$. for 30 minutes. A duplicate sample is used to determine the $\mathrm{pH}$ of the digestion mixture. By use of Figure 4, the amount of albumen which would have been digested at $\mathrm{pH} 1.75$ (the digestion $\mathrm{pH}$ of the dilute test) is determined.

Because the lines represented in Figure 3 have the same slope, it is possible to extrapolate the results obtained at $1 / 4$ dilution to zero dilution.

After adjusting for the differences in kinetics of the two tests, results are again expressed in pepsin equivalents as before. The units thus derived give values for the active pepsin which are comparable to those for total pepsin. Since the units are comparable the percentage of pepsin inhibited is easily derived from the figures for total pepsin and active pepsin.

\section{Resting peptic activity}

Since the active pepsin fraction is expressed as the activity at $\mathrm{pH} 1.75$, it will not represent the activity of the gastric juice at its own $\mathrm{pH}$ occurring in vivo.

After obtaining the $\mathrm{pH}$ of the gastric juice, the active pepsin fraction is corrected to the activity at that $\mathrm{pH}$ by reference to Figure 4.

This value shows the summation of the effect of inhibitory substances and $\mathrm{pH}$ characteristic of a specimen of gastric juice collected during a basal secretory state. It should be remembered that this is an artificial comparison because the effect of $\mathrm{pH}$ is on the substrate and not on the enzyme. It really represents the activity which would result if the enzyme concentration were reduced at a constant $\mathrm{pH}$.

\section{Peptic activity in human subjects}

A total of 132 fasting specimens of human gastric juice was obtained from the Gastrointestinal Clinic of the University of Chicago Clinics ${ }^{4}$ and the determinations earlier described were made. Out of this number we selected juice from every case of proved duodenal ulcer, totaling 30 cases. All patients had x-ray evidence of ulcer.

Twenty-one fasting specimens of gastric juice were collected from 21 of the students, interns, and resident staff of the Clinics. The criteria for normality were absence of past or present gastrointestinal disease or symptoms.

4 Through the courtesy of Dr. Walter L. Palmer. 
TABLE I

Pepsin activity of gastric juice

30 duodenal ulcer subjects 21 normal subjects

\begin{tabular}{|c|c|c|c|c|c|c|c|}
\hline \multicolumn{2}{|c|}{$\begin{array}{l}\text { Total pepsin } \\
\text { activity. } \\
\text { Pepsin equiva- } \\
\text { lents per ml. }\end{array}$} & \multicolumn{2}{|c|}{$\begin{array}{l}\text { Active pepsin } \\
\text { fraction. } \\
\text { Pepsin equiva- } \\
\text { lents per ml. }\end{array}$} & \multicolumn{2}{|c|}{$\begin{array}{l}\mathrm{pH} \text { of gastric } \\
\text { juice }\end{array}$} & \multicolumn{2}{|c|}{$\begin{array}{l}\text { Resting peptic } \\
\text { activity. } \\
\text { Pepsin equiva- } \\
\text { lents per ml. }\end{array}$} \\
\hline Normal & Ulcer & Normal & Ulcer & Normal & Ulcer & Normal & Ulcer \\
\hline $\begin{array}{r}2,500 \\
3,400 \\
4,300 \\
4,300 \\
313 \\
7,500 \\
188 \\
1,900 \\
6,100 \\
250 \\
6,100 \\
8,600 \\
4,300 \\
3,900 \\
3,900 \\
3,600 \\
2,800 \\
6,100 \\
7,500 \\
1,600 \\
2,800\end{array}$ & $\begin{array}{r}2,500 \\
3,900 \\
3,000 \\
5,200 \\
2,700 \\
3,600 \\
2,500 \\
6,200 \\
940 \\
4,900 \\
2,500 \\
6,200 \\
8,700 \\
5,400 \\
4,800 \\
11,200 \\
3,600 \\
2,500 \\
4,900 \\
4,100 \\
1,300 \\
1,000 \\
5,200 \\
3,600 \\
4,300 \\
3,400 \\
3,900 \\
4,900 \\
3,000 \\
2,500\end{array}$ & $\begin{array}{l}2.6 \\
1.7 \\
0.6 \\
4.4 \\
1.1 \\
2.2 \\
0.6 \\
1.7 \\
1.0 \\
0 \\
1.5 \\
1.3 \\
1.2 \\
1.1 \\
1.1 \\
1.2 \\
0.9 \\
0.8 \\
2.8 \\
1.1 \\
5.6\end{array}$ & $\begin{array}{l}1.2 \\
1.0 \\
1.1 \\
1.2 \\
1.3 \\
1.7 \\
1.3 \\
1.6 \\
1.8 \\
1.3 \\
1.0 \\
1.2 \\
1.4 \\
1.9 \\
1.0 \\
1.8 \\
1.0 \\
1.0 \\
1.3 \\
1.0 \\
1.9 \\
1.3 \\
1.6 \\
0.9 \\
1.1 \\
0.6 \\
1.3 \\
1.4 \\
1.1 \\
0.9\end{array}$ & $\begin{array}{l}5.12 \\
3.25 \\
1.85 \\
1.50 \\
4.90 \\
1.50 \\
7.45 \\
4.55 \\
1.80 \\
6.45 \\
1.50 \\
1.60 \\
1.80 \\
1.55 \\
2.55 \\
2.70 \\
1.55 \\
2.25 \\
1.40 \\
3.55 \\
3.70\end{array}$ & $\begin{array}{l}1.35 \\
2.55 \\
2.15 \\
1.45 \\
1.10 \\
2.20 \\
1.40 \\
1.50 \\
2.10 \\
2.0 \\
1.50 \\
2.30 \\
1.50 \\
1.45 \\
3.10 \\
1.50 \\
1.40 \\
1.50 \\
1.30 \\
1.50 \\
1.80 \\
1.30 \\
1.55 \\
1.50 \\
1.65 \\
1.40 \\
1.50 \\
1.25 \\
1.60 \\
1.50\end{array}$ & $\begin{array}{l}0.5 \\
0.8 \\
0.6 \\
5.9 \\
0.8 \\
2.8 \\
0 \\
0.6 \\
0.9 \\
0 \\
1.9 \\
1.5 \\
1.1 \\
1.3 \\
0.7 \\
0.8 \\
1.0 \\
0.7 \\
4.2 \\
0.6 \\
1.1\end{array}$ & $\begin{array}{l}1.5 \\
0.7 \\
0.9 \\
1.5 \\
1.9 \\
1.1 \\
1.6 \\
2.1 \\
1.3 \\
1.1 \\
1.1 \\
0.8 \\
1.7 \\
2.5 \\
0.6 \\
2.2 \\
1.1 \\
1.1 \\
1.7 \\
1.1 \\
1.8 \\
1.8 \\
1.9 \\
1.0 \\
1.1 \\
0.7 \\
1.5 \\
2.0 \\
1.1 \\
1.0\end{array}$ \\
\hline
\end{tabular}

RESULTS

The results of the $\mathrm{pH}$ determinations on the ulcer patients and on the normal human beings are depicted in Table I. One may note that 28 out of 30 ulcer patients, or 92 per cent, had $\mathrm{pH}$ values below 2.4, whereas only 11 out of 21 of the normal group, or 52 per cent had high free acid values in the corresponding $\mathrm{pH}$ range (Figure 6). This is in fair agreement with what has been described in the literature by other investigators $(1,2)$.

An examination of the peptic activity of the gastric juices of our human subjects, as illustrated in Table I, reveals the following:

Total pepsin activity. It is notable that there is wide individual variation in the total pepsin activity (or pepsin content) among both the normal and the ulcer groups. Despite this variation, statistical comparison of the two groups as a whole reveals no significant difference.

Active pepsin fraction. Here one may see that the amount of inhibitory substances present is of a huge magnitude for all individuals in both groups, for the actual amount of active pepsin present is very small. Notwithstanding the wide individual variation in total pepsin activity existing among individuals in each group, the active pepsin fraction does not exhibit the same trend, but rather there is close uniformity in the quantity

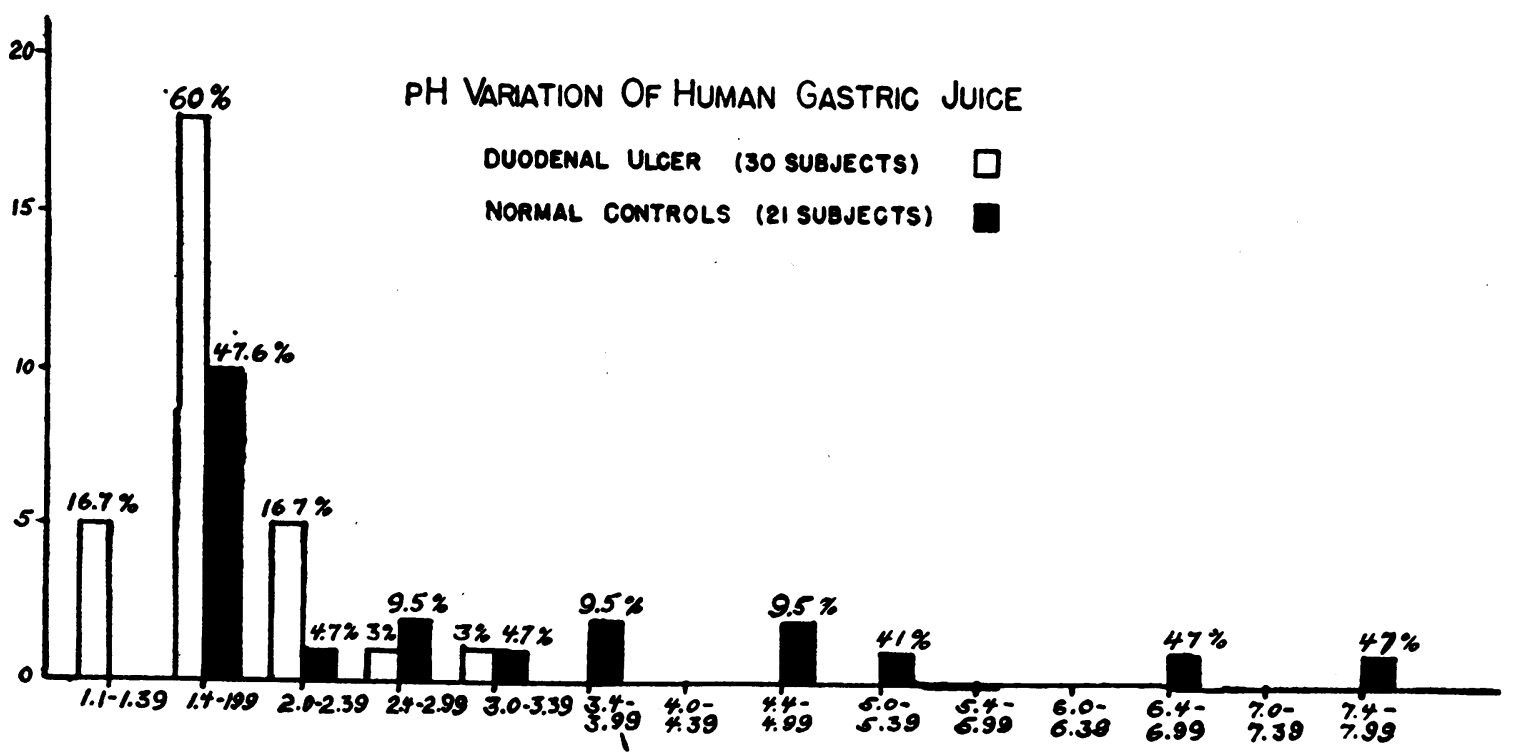

Fig. 6. Shows the Distribution of Cases According to their Gastric Acidity in pH Units 


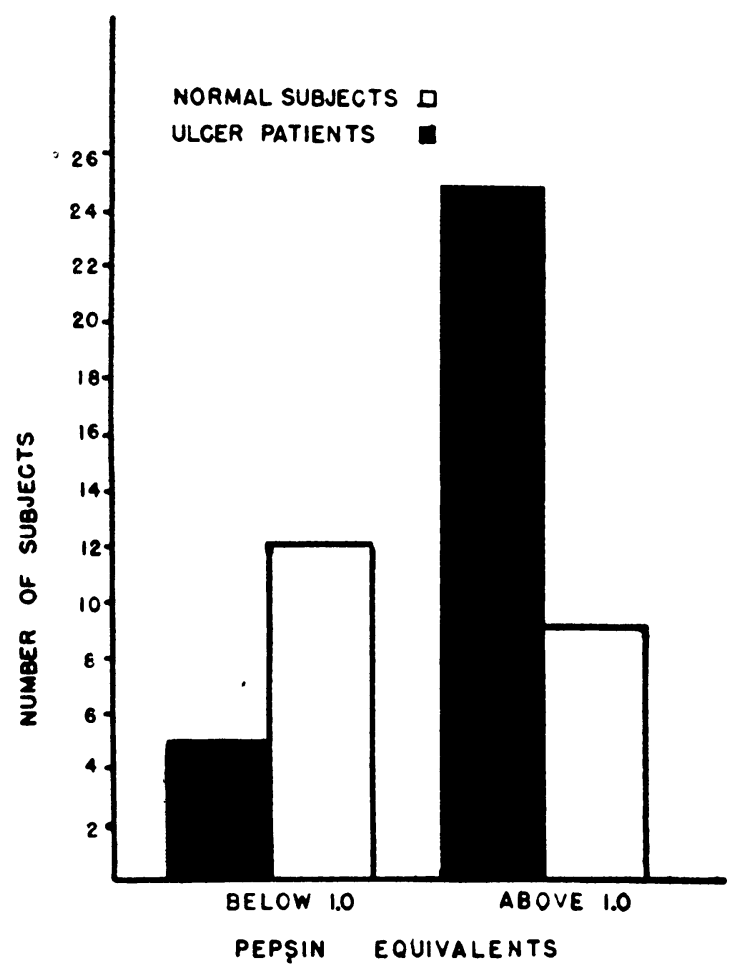

Fig. 7. The Number of Cases Having Resting Peptic Activity Above and Beiow the Value of 1 is ILLUSTRATED

of pepsin in both groups. Again, statistical comparison between the two groups shows no significant difference.

Per cent pepsin inhibition. This illustrates again the enormous amount of inhibition present and the uniformity of this phenomenon in all the individuals studied. In all but one case, more than 99 per cent of the total pepsin is inhibited, and in most, there is $99.9+$ per cent inhibition.

The percentage of the total pepsin which is active in the presence of the pepsin inhibitory substances of the gastric juice is exceedingly small. With the crystalline pepsin used by us, the quantity of active pepsin present ranges approximately from 0.05 gamma to 0.15 gamma per ml., as compared with an average figure of approximately 270.0 gamma per ml. of total pepsin in both groups.

Resting peptic activity. This estimation of the actual in situ digestive activity of the gastric juice, expressed in pepsin equivalents, is also contained in the table.

It is here that one may note the effect of $\mathrm{pH}$ of the gastric juice on the active pepsin fraction.
Precursory inspection may not reveal a striking change because of 3 abnormally high results in the normal group. However, the majority of ulcer cases, 25 out of 30 , have pepsin activities of 1.0 pepsin equivalents or above, whereas less than half, 9 out of 21 normal subjects, have like values. This is pictured in Figure 7 . That this result is significant has been proved by the Chi Square Method of Statistical Analysis $\left(x^{2}=9.1\right)$.

\section{DISCUSSION}

From the evidence presented, it is manifest that the major differences between the two groups lie in the $\mathrm{pH}$ and resting peptic activity. The active pepsin fraction, percentage of inhibition, and total pepsin concentration are almost identical in the two groups.

It is noteworthy that our findings of similar total pepsin concentrations in the normals and in ulcer patients are at variance with the reports of other investigators $(10,11,12)$. A criticism that might be made of our findings is the relative smallness of the series: However, the number of cases studied is statistically adequate. We feel that the findings of others quoted $(10,12)$ may be open to criticism on the basis of error inherent in their method of pepsin determination, as mentioned previously. Vanzant et al (10) and Mullins and Flood (11) both used low dilutions of gastric juice, which resulted in the assay, not of total pep$\sin$, but of a variable mixture of pepsin and pepsininhibitor complex. Both also obtained their gastric specimens after test meal stimulation. There is some indication that the test employed by Osterberg et al was subject to error because of insufficient buffering of their digestion mixture. In our experience, even strong buffers will not maintain a constant digestion $\mathrm{pH}$ when mixed with equal volumes of gastric juice. We have occasionally observed unusually high fasting values of total pepsin in ulcer patients, but the group as a whole does not vary significantly from the normals.

The observation that $99+$ per cent of the pepsin is inhibited might seem incredible at first . Examination of Figure 1 relating quantity of albumen digested per unit time reveals a rapid initial rate becoming negligible after 30 minutes. Inasmuch as the rate of digestion is directly proportional to the concentration of active enzyme and since the 
rate of digestion becomes practically nil, it follows that there must be an extremely small amount of active enzyme present. The pepsin in resting gastric contents is constantly acting on protein substrate (cells, mucin, and protein secreted), and one might expect that it is almost completely inhibited for the same reason. This may well be one of the reasons that the stomach does not digest itself. Formerly, one remarked at the amazing ability of the stomach and duodenum to resist digestion. Now it can be seen that these organs actually have very little to resist and that instead of being resistant, they are probably quite susceptible. The inability of these organs to resist digestion is indicated by those animal experiments in which the feeding or irrigation of bowel with active pepsinhydrochloric acid mixture quite uniformally and rapidly produced ulceration $(13,14,15)$. The rapidity with which apparently normal humans develop perforation and bleeding under certain emotional stresses (32) also, the rapidity with which peptic ulcers sometimes develop after burns (33) would seem to indicate that the mucosa is not resistant to attack by active gastric juice. Herein also may lie the explanation of how ulcers, produced by the ingestion of acid in the experimental animal (4), may result from dilution of inhibitor substances and also further enhancement of the enzyme action by the increased hydrogen ion concentration. Hypersecretion also, by continually diluting the inhibitor substances, might sustain active pepsin at relatively high levels.

The extremely low values of the active pepsin fraction would tend to support the contention that very little pepsin is necessary to produce mucosal ulceration via the digestion mechanisms. Despite the high percentage of observed inhibition, the pep$\sin$ is not really destroyed, and is readily. made available for digestion by the process of dilution. There is a huge pepsin reserve; the digestive power of gastric juice can be increased 5,000 times by simple dilution. As mentioned in the section on kinetics, even the addition of a sizable increment of pepsin to a pepsin solution with a high concentration of inhibitor will produce little increase in digestive action. For this reason, the actual digestibility of gastric juice does not vary appreciably with excessive increases in pepsin content. Driver (14) found that doubling the pepsin con- centration did not alter the extent or frequency of ulceration observed when perfusing isolated loops of small intestine. His perfusion was carried out at the rate of $2 \mathrm{ml}$. per minute through a loop of bowel that would hold many times that volume. The perfusion was certainly not rapid enough to wash out the inhibitors that formed during the process of peptic digestion, and thus one may conclude that the active pepsin fraction was not significantly elevated. In the discussion on kinetics, it was stated that the amount of albumen digested is not in linear proportion to the pepsin concentration. Therefore, increasing the concentration of pepsin should not change the ulcerating power markedly either in the dog experiments of Driver (14) or the frog experiments of Dragstedt (5). Matthes (34) who was one of the first to irrigate loops of bowel in dogs with pepsin-hydrochloric acid mixtures and gastric juice, concluded that peptones found in gastric juice combined with the free acid and in this way reduced its ulcerating ability. Langenskiöld (28) came to similar conclusions. Their work, however, really lends excellent support to the thesis that ulcers are the product of peptic digestion since the peptones more effectively combine with the pepsin.

Even though large changes in the pepsin concentration do not produce appreciable increase in pepsin activity, small changes in hydrogen ion concentration will produce marked changes in digestive action (Figure 4). Hence this mechanism is by far the most important in controlling the digestive action in vivo. It can therefore be established that the $\mathrm{pH}$ is of greater importance in controlling resting peptic activity than the total pepsin content of the gastric juice. On comparison of the resting peptic activity of the normals with those of ulcer patients, one sees no clear-cut division between the two groups. Some normals, drawn from medical students and interns, had high gastric acidity and therefore high resting peptic activity. In some cases these individuals said they were hungry because they had missed their accustomed breakfast; others were apprehensive and had difficulty swallowing the tube. The studies of Wolf and Wolff (35) on Tom, a man with a stricture of the esophagus and a large gastric fistula, have shown that emotional stimuli such as resentment and anxiety will increase hydrochloric 
acid production tremendously. Also, hunger will produce copious secretion of hydrochloric acid and pepsin. We have not excluded these normals from our series, however, since the ulcer patients have probably experienced the same stimuli. Many of both groups, therefore, were in a secretory state rather than a basal state. True resting contents are well-nigh impossible to obtain under the usual clinical conditions (36). One may always expect some high values in the group. The best method of comparing these two groups is by statistical means. When such a comparison is made the results have been shown to be highly significant.

A better method of investigation than ours for obtaining basal secretory levels would be gastric aspiration during sleep. Winkelstein (37) and others $(38,39)$ have pointed out that the free hydrochloric acid falls to zero or very low in normal patients during sleep; yet, in sharp contrast, increased values are found in ulcer patients. Such a study, however, necessitates hospitalization.

These present observations on gastric juice while highly suggestive do not prove that ulcer development is a function of the resting peptic activity. One must prove that the ability of pepsin solution to digest a given protein substrate is the same as its ability to produce experimental ulcers.

Experiments (24) have been conducted wherein the mucosal and serosal surfaces of dogs' intestines were irrigated with hydrochloric acid-pepsin solutions adjusted so that the $\mathrm{pH}$ of one pepsin mixture was kept at 1.50 and the other at 2.15. This made the peptic activity of the $\mathrm{pH} 2.15$ mixture 60 per cent of that of the $\mathrm{pH} 1.50$ preparation (Figure 4). The activity of the former solution was doubled, however, by increasing its temperature $10^{\circ} \mathrm{C}$. (van't Hoff's Law) so that its final activity was 20 per cent greater than that of the more acid solution. (The irrigation temperature was $30^{\circ} \mathrm{C}$. for the $\mathrm{pH} 1.5$ solution and $40^{\circ} \mathrm{C}$. for the other.) By this means the pepsin activity of the less acid solution was the greater. Ulcers formed more readily and were more extensive both on the mucosal and serosal surfaces of the bowel with the low acid-high peptic activity mixture. Bowel irrigated with hydrochloric acid alone ( $\mathrm{pH} 1.5$ and at $40^{\circ} \mathrm{C}$.) exhibited no ulceration. When conditions other than temperature variations were sought to reduce peptic activity, it was found that 2 per cent solution of neopeptone ("Difco") reduced the amount of albumen digested by 50 per cent. Bowel was irrigated with two acid pepsin solutions both at $\mathrm{pH} 1.5$ but one containing 2 per cent neopeptone. Neopeptone protected against the development of ulcers. It will be remembered that Matthes (34) had concluded that peptone in gastric juice by reducing the free acid had lessened its ulcerating effect. In the experiment reported, acid was added to the solution containing neopeptone to make the $\mathrm{pHs}$ identical, yet the solution containing neopeptone did not readily form ulcers. Such exclusive experiments would tend to indicate that peptic activity plays a major role in the production of ulcers.

\section{CONCLUSIONS}

Enzyme kinetics, together with quantitative methods for the determination of total pepsin concentration and inhibitor substances, have been applied in a physiological study of the products of gastric secretion in 31 proved ulcer patients and 21 normal subjects.

The resting peptic activity was found to be significantly greater in the ulcer group. This increase was dependent upon the higher acidity of the gastric juice in the ulcer patients, for there was no increase in total gastric pepsin in this group. The reason that an increase in total pepsin content of gastric juice does not significantly alter peptic activity is that pepsin inhibitor substances are present.

The inhibitor substances present in the gastric juice produce more than 99 per cent inhibition of pepsin in both the normal and the ulcer groups. This, in conjunction with the probable low basal levels of free hydrochloric acid in normal patients, prevents autodigestion.

It would appear that ulcers are really the product of peptic digestion, and that the $\mathrm{pH}$ of the gastric juice is by far the most important regulator of the peptic activity, even to the exclusion of pepsin concentration.

It is believed that strict application of the laws of enzyme chemistry has elucidated some discrepancies which have resulted from the inadequate qualitative experiments of the past on gastric digestion. 


\section{ACKNOWLEDGMENT}

Gratitude is expressed to Dr. Dallas B. Phemister and Dr. William H. Fishman for their aid in the preparation of this manuscript.

\section{BIBLIOGRAPHY}

1. Sagal, Z., Marks, J. A., and Kantor, J. L., The clinical significance of gastric acidity. A study of 6679 cases with digestive symptoms. Ann. Int. Med., 1933, 7, 76.

2. Vanzant, F. R., Alvarez, W. C., Berkson, J., and Eusterman, G. B., Changes in gastric acidity in peptic ulcer, cholecystitis, and other diseases (analyzed with the help of a new and accurate technique). Arch. Int. Med., 52, 616, 1933.

3. Dragstedt, L. R., Pathogenesis of gastroduodenal ulcer. Arch. Surg., 1942, 44, 438.

4. Mann, F. C., and Bollman, J. L., Experimentally produced peptic ulcers; development and treatment. J. A. M. A., 1932, 99, 1576.

5. Dragstedt, L. R., Acid Ulcers. Surg. Gyn. \& Obstet., 1936, 62, 118.

6. Vineberg, A. M., and Babkin, B. P., Histamine and pilocarpine in relation to the gastric secretion. Am. J. Physiol., 1931, 97, 69.

7. Gillman, A., and Cowgill, G. R., The effect of histamine upon the secretion of gastric pepsin. Am. J. Physiol., 1931, 97, 124.

8. Hay, L. J., Varco, R. L., Code, C. F., and Wangensteen, O. H., The experimental production of gastric and duodenal ulcers in laboratory animals by the intramuscular injection of histamine in beeswax. Surg. Gynec. \& Obstet., 1942, 75, 170.

9. McHardy, G., and Browne, D. C., Duodenal ulcer developing in man following "histamine desensitization." Gastroenterology, 1944, 2, 345.

10. Vanzant, F. R., Osterberg, A. E., Alvarez, W. C., and Rivers, A. B., Studies of gastric pepsin. II. Secretion of pepsin in cases of duodenal ulcer and pseudo-ulcer. J. Clin. Invest., 1933, 12, 557.

11. Mullins, C. R., and Flood C. A., A study of gastric pepsin in various diseases. J. Clin. Invest., 1935, 14, 793.

12. Barowsky, H., Upham, R., Dotti, L. B., and Kleiner, I. S., Clinical significance of concentration of pepsin in gastric juice. Rev. Gastroenterol., 1943, 10, 201.

13. Schiffrin, M. J., and Warren, A. A., Factors (especially gastric acidity and pepsin) concerned in the production of experimental ulceration of the gastrointestinal tract of cats. Am. J. Digest. Dis., 1942, 9, 205.

14. Driver, R. L., Chappell, R. H., and Carmichael, E. B., Effect of concentration of pepsin and differential susceptibility of jejunal segments in experimental ulcers in dogs. Am. J. Digest. Dis., 1945, 12, 166.
15. Matzner, M. J., Windwer, C., Sobel, A. E., and Polayes, S. H., Role of pepsin in experimental production of gastric ulcer in rats. Proc. Soc. Exper. Biol. \& Med., 1936, 34, 243.

16. Le Veen, H. H., Total peptic activity of gastric juice, a method of determination. Proc. Soc. Exper. Biol. \& Med., 1946, 63, 254.

17. Waldschmidt-Leitz, E., Enzyme Action and Properties. J. Wiley \& Sons, N. Y. 1929, p. 134.

18. Tiselius A., and Eriksson-Quensel, I., Some observations on peptic digestion of egg albumen. Biochem. J., 1939, 33, 1752.

19. Bergmann, M., and Fruton, J. S., The specificity of proteinases. Advances Enzymol., 1941, 1, 63.

20. Northrop, J. H., The effect of concentration of enzyme- - n the rate of digestion of proteins by pepsin. J. Gen. Physiol., 1920, 2, 471.

21. Northrop, J. H., The influence of substrate concentration on the rate of hydrolysis of proteins by pepsin. J. Gen. Physiol., 1920, 2, 595.

22. Hitchock, D. L., In Schmidt's "The Chemistry of the Amino Acids and Proteins." 2nd edition. Charles C. Thomas Springfield, Ill., 1945, p. 596.

23. Ringer, W. E., Quoted by Northrop, J. H., Combination of enzyme and substrate. II. Effect of hydrogen ion concentration. J. Gen. Physiol., 1920, 2, 113.

24. Le Veen, H. H., Chemical, Physiological, and Pathological observations on the role of pepsin and hydrochloric acid in the production of experimental ulcers. Gastroenterology, 1947, 8, 648.

25. Nirenstein, E., and Schiff, A., IV. Uber die pepsinbestimung nach mette und die nothwendigkeit ihrer modification für klinische zwecke. Berlin. Klin. Wchnschr., 1903, 40, 268.

26. Hensel-Quoted by Komarov, S. A., Inactivation of pepsin and its relation to peptic ulcer. Rev. Gastroenterol., 1942, 9, 165.

27. Blum, L., and Fuld, E., Uber das Vorkommen eines Antipepsin in Magenshaft. Ztschr. F. Klin. Med., 1906, 58, 505.

28. Langenskiöld, F., Uber die widerstandsfähigkeit einiger lebender Gewebe gegen die Einwirkung eiweisspaltender Enzyme. Skand. Arch. F. Physiol., 1914, $31,1$.

29. Bucher, G. R., Grossman, M. I., and Ivy, A. C., A pepsin method: The role of dilution in the determination of peptic activity. Gastroenterology, $1945,5,501$.

30. Le Veen, H. H., Active pepsin fraction, resting peptic activity, and percentage of pepsin inhibition gastric juice. Proc. Soc. Exper. Biol. \& Med., 1946, 63, 259.

31. Wiss, O., Investigations into proteases (1) amino acids, hydrocyanic acid, pyrophosphates as effectors of pepsin. Helvetica Chimica Acta, 1946, 29, 237.

32. Davies, D. T., and Wilson, A. T. M., Personal and clinical history in hematemesis and perforation. Lancet, 1939, 2, 723. 
33. Harkins, H. N., Acute ulcer of the duodenum (Curling's Ulcer), as a complication of burns; relation to sepsis. Surgery, 1938, 3, 608.

34. Matthes, Max, Untersuchung über die Pathogenese des Ulcus rotundum ventriculi und über den Einfluss von Verdauungsenzym auf lebendes und todtes Gewebe. Beitr. Path. Anat. u. F. Allg. Path., 1893, 13, 309.

35. Wolf, S., and Wolff, H. G., Human Gastric Function. Oxford University Press, N. Y. 1943, p. 109.

36. Bloomfield, A. L., Chen, C. K., and French, L. R., Basal gastric secretion as a clinical test of gastric function with special reference to peptic ulcer. J. Clin. Invest., 1940, 19, 863.

37. Winkelstein, A., One hundred and sixty-nine studies in gastric secretion during the night. Am. J. Digest. Dis. \& Nutrition, 1935, 1, 778.

38. Henning, N., and Norpoth, L., Die Magensekretion während des Schlafes. Deut. Arch. F. Klin. Med., 1932, 172, 558.

39. Mittelmann, B., and Wolff, H. G., Emotions and gastroduodenal function; experimental studies on patients with gastritis, duodenitis and peptic ulcer. Psychosom. Med., 1942, 4, 5. 